\title{
TO THE QUESTION OF FORMATION OF COMPETENCE RESEARCH SKILLS OF FUTURE TEACHERS OF HIGHER EDUCATION INSTITUTIONS
}

Balashova Svitlana, PhD in Pedagogic Sciences, Associate Professor, Taras Shevchenko National University of Kyiv.

ORCID 0000-0003-2400-7867

E-mail: sbalashova@ukr.net

Holovko Nataliia, PhD in Pedagogic Sciences, Associate Professor, Taras Shevchenko National University of Kyiv.

ORCID: 0000-0003-4859-2837

E-mail: Golovkonata@ukr.net

The basic approaches to the formation of research skills of students as future teachers were revealed; the content and structure of pedagogical evaluation of research skills, technologies of its implementation and possibilities of application in the process of formation of research skills of students; the method of pedagogical evaluation of research skills was described.

In today's high school pedagogical diagnostics as the practice of identifying quality educational activities and the reasons for its successes and failures plays a significant role.

Keywords: research skills, pedagogical diagnostics, future teachers, institutions of higher education, innovation, student youth competence, stages of development research, competence approach.

\section{ДО ПИТАННЯ ФОРМУВАННЯ ДОСЛІДНИЦЬКИХ УМІНЬ У МАЙБУТНІХ ВИКЛАДАЧІВ ЗАКЛАДІВ ВИЩОЇ ОСВІТИ}

Балашова Світлана, кандидат педагогічних наук, доцент, Київський національний університет імені Тараса Шевченка.

ORCID: 0000-0003-2400-7867

E-mail: sbalashova@ukr.net

Головко Наталія, кандидат педагогічних наук, доцент, Київський національний університет імені Тараса Шевченка.

ORCID: 0000-0003-4859-2837

E-mail: Golovkonata@ukr.net

\begin{abstract}
Вирімення проблеми формування дослідницьких умінь у практичній діяльності закладів вищої освіти безпосередньо пов'язано з впровадженням методів оцінювання дослідницьких умінь студентів в освітньому просторі і внесенням на їх основі коректив у форми і методи навчання, які сприяють розвитку їх як фахівия-дослідника.

У сучасній вищій школі значне місие посідає також педагогічна діагностика як практика виявлення якості освітньої діяльності. Активізація уваги до педагогічної діагностики пов'язана з впровадженням в освітню діяльність нових педагогічних технологій, які спрямовані на формування творчого потенціалу майбутнього фахівцяя. Педагогічне оцінювання дослідницьких умінь майбутніх викладачів проводилося на основі розробленого та теоретично обгрунтованого змісту, структури (аналітико-синтетичні, креативні, інформаційні, прогностичні) оцінювання їх рівня сформованості (високий, середній, низький).
\end{abstract}




\begin{abstract}
Перспективою подальших досліджень вбачаємо поглиблене вивчення зарубіжного досвіду використання різновидів педагогічної діагностики щчодо визначення рівня сформованості творчих можливостей студентів, зокрема дослідницьких умінь.

Досліднииький профіль студента дозволяє викладачам педагогічного колективу університету спрямувати свою діяльність на розвиток дослідницьких умінь студентів, керувати иим процессом, а ткож дає можливість проаналізувати окремі групи дослідницьких вмінь з метою їх посиленого розвитку у освітньому процесі.

Аналіз дослідницьких умінь кожного студента групи дає змогу проаналізувати «дослідницький портрет» навчальної групи студентів $i$ дати обгрунтовані рекомендачії викладачам, методистам щодо підвищення ефективності освітнього процесу, спрямування його розвиток дослідницької діяльності студентів.

Ключові слова: дослідницькі навички, педагогічна діагностика, майбутні вчителі, вищі навчальні заклади, інновації, компетентність студентської молоді, етапи досліджень розвитку, компетентнісний підхід.
\end{abstract}

In the conditions of realization of the humanistic paradigm of higher education, it is expedient and necessary to carry out the professional training of the future teacher as a researcher, which will ensure the orientation of the educational process to the creative development of the students' personality, satisfaction of their interests and educational needs. Pedagogical activity of the teacher in its essence is a scientific search, creative activity, has a pronounced research character. Therefore, professional training of future teachers as researchers is possible in the conditions of their formation in the process of studying educational disciplines, which involves theoretical substantiation and development of the structure and content of research skills, criteria for their formation; development of pedagogical technology for their formation in future teachers in the process of studying academic disciplines in a higher educational institution. The developed pedagogical technology of formation of research skills in the future specialists includes pedagogical estimation of the level of formation of their research skills.

The purpose of this article is to reveal the content and structure of the pedagogical evaluation of research skills, the technology of its implementation and the possibilities of its application in the process of formation of students' research skills in higher education institutions.

Analysis of the range of different scientific sources showed that in recent years in teaching science special attention was paid to the problems of professional training of the future teacher. In today's high school an important place pedagogical diagnostics as the practice of identifying quality educational activities, the reasons for its successes and failures. Activation of attention to educational assessment linked to the introduction of new educational technologies aimed at forming creative potential of the future expert. This problem was explored both by native and foreign scientists: V. Buyanin, K. Zaripova, K. Ingenkamp, B. Kobzar, A. Kochetov, O. Leontiev, O. Luria, K. Tarnasova, L. Spirina, M. Frumkina and other. They carried out a thorough analysis of pedagogical diagnostics, in particular, the content and specificity of pedagogical diagnostics were substantiated, its stages and methodology were determined (B. P. Bitinas, N. M. Levina, I. Ya. Lerner, etc.); the methods of pedagogical diagnostics are determined (K. Ingenkamp, K. Klauer et al.); A system of training future teachers for diagnostic activities was developed (O. Grebenyuk, A. Grigoriev, I. Zhitko, V. Bondar, I. Zyazyun, S. Sysoev, G. Tarasenko, L. Horuzh, and others). In recent years, a significant amount of research is devoted to the development of individual areas of diagnostic activity (I. Zhitko, M. Zakharichich, L. Kravchenko, etc.). 
According to the leading researchers, the problem of pedagogical diagnosis in the educational process is intended, firstly, to optimize the process of individual learning, secondly, in the interests of society to ensure the correct definition of learning outcomes and, thirdly, guided by the developed criteria, to minimize mistakes in the transfering students from one specialty to another, when they are sent to different courses in the choice of specialization training. Based on the analysis of scientific sources, we came to the conclusion that diagnostic activity is a process in which, (using diagnostic tools or without it) following the necessary scientific criteria of quality, the teacher observes the objects of study and conducts questionnaires, pedagogical evaluation of general and professional competences, processes data of observations and polls and reports on the results obtained in order to direct the future specialist to the chosen profession, an explanation of its motives or predictive behaviors in the future.

A number of researchers determined the nature of pedagogical diagnostics as a study of the effectiveness of the educational process in higher education institutions on the basis of changes in the level of education, as well as the growth of teaching skills.

In our opinion, pedagogical diagnostics is a pedagogical method in a holistic system that combines the tasks of analysis and control, modulation and prediction of relations in the categories "purpose - means - result" and the definition of necessary adjusting influences. Based on the analysis of psychological and pedagogical sources, we came to the conclusion that the process of forming the terminology apparatus of pedagogical diagnostics has not been completed to date. However, despite this factor, pedagogical diagnosis has a great importance in practical work.

Solving the problem of developing research skills in the practical activities of higher education institutions is directly related to the introduction of methods for assessing the research skills of students in the educational space and the introduction on their basis of corrections in the forms and methods of teaching that contribute to their development as specialists [1].

Pedagogical evaluation of the research skills of future teachers was conducted on the basis of the developed and theoretically substantiated content, structure (analytical, synthetic, creative, informational, predictive) research skills and criteria of evaluation of their level of formation (high, medium, low).

The study of the state of the formation of research skills in the educational process of higher educational institutions began with the clarification of the readiness of teachers and students for pedagogical activities. We applied the method of questioning. The survey of university students shows that a significant number of students (74\% of 548 respondents) were little acquainted with the notion of "research skills", "research pedagogical activity", with the system of student research work, etc. Most of the teachers who participated in the survey are knowledgeable in the concepts of "research pedagogical activity", "research skills", are guided by methods of pedagogical research ( $86 \%)$, but are hampered by the low level of readiness of teachers to attract students to research activities.

We have developed a methodology for pedagogical evaluation of research skills, which includes:

1) the choice of experts from the teaching staff and seminars;

2) student observation during classroom and pedagogical practice;

3) filling the diagnostic maps of the level of the formation of research skills by experts; 
4) self-assessment of research skills by students;

5) determining the level of formation of research skills;

6) making corrections in the educational process for improving the formation and development of research skills of future specialists;

7) implementation of the educational process on the basis of corrections made.

Investigation of research skills of students we conducted by the method of independent expert evaluations to determine the level of their formation.

We picked up a group of experts from teachers who knew each student research skills. Therefore, we have attracted expert evaluations of teachers who directly contact with students during the educational process and pedagogical and other types of practice, as well as have a pedagogical experience of work in institution of higher education for at least three years.

Before starting the study, a seminar was organized for the experts, teachers, during which they were acquainted: firstly, with the content, structure and criteria for evaluating research skills; secondly, with the content of theoretical and practical aspects of pedagogical evaluation, the technology of filling in diagnostic cards; thirdly, pedagogical technology of forming students' research skills.

For a pedagogical assessment of the level of formation of students' research skills a diagnostic card was filled (Table 1).

Having completed with a diagnostic card, the high, middle and low levels correspond to the following quantitative indicators: high level - "3.6" - "5" points; the average level is "1.8" - "3.5" points; the low level is " $0 "$ - " 1.7 " points.

Following the independent experts' assessment of the students' research skills, a summary score (average expert score) is presented, which characterizes the level of students' research skills [2].

In conducting an assessment of the level of formation of students' research skills, as one of the expert assessments, we took into account students' self-esteem. Each student received a diagnostic card, where he filled in information about the name of the higher education institution, the direction of studying, the name of the specialty, the date of conducting, and also indicated his surname and name. A seminar was held with students from each training group, where the content of research skills, criteria and technology for evaluating research skills was disclosed. Study of the students' self-esteem was done by direct interviews with students using questionnaires, creative tasks, diagnostic tests, trainings, etc.

\section{The table of the study of the formation of research skills of Smirnova Marina course 1 Taras Shevchenko Kyiv National University}

\begin{tabular}{|l|c|c|c|c|c|c|c|}
\hline Research skills & $\begin{array}{c}\text { Expert } \\
\# \mathbf{1}\end{array}$ & $\begin{array}{c}\text { Expert } \\
\# \mathbf{2}\end{array}$ & $\begin{array}{c}\text { Expert } \\
\# \mathbf{3}\end{array}$ & $\begin{array}{c}\text { Average } \\
\text { expert } \\
\text { estimate }\end{array}$ & $\begin{array}{c}\text { Student } \\
\text { self- } \\
\text { esteem }\end{array}$ & $\begin{array}{c}\text { Average } \\
\text { overall } \\
\text { score }\end{array}$ & $\begin{array}{c}\text { Level of } \\
\text { formation } \\
\text { of research } \\
\text { skills }\end{array}$ \\
\hline 1 & 2 & 3 & 4 & 5 & 6 & 7 & 8 \\
\hline $\begin{array}{l}\text { 1. Analytical and synthetic skills } \\
\text { - ability to analyze, -synthetic information }\end{array}$ & 1,5 & 1,5 & 1,5 & 1,5 & 3,5 & 2,0 & $\mathrm{~A}$ \\
\hline - the ability to highlight the main thing & 2 & 1,5 & 1,5 & 1,66 & 3,5 & 2,58 & $\mathrm{~A}$ \\
\hline - ability to describe phenomens, processes & 1 & 1 & 1 & 1 & 4 & 1,77 & $\mathrm{~L}$ \\
\hline
\end{tabular}

\section{ISSN 2706-6258}




\begin{tabular}{|l|c|c|c|c|c|c|c|}
\hline $\begin{array}{l}- \text { the ability to systematize, to classify } \\
\text { scientific information }\end{array}$ & 1 & 1 & 1 & 1 & 3 & 1,5 & $\mathrm{~L}$ \\
\hline $\begin{array}{l}\text { 2. Information skills: } \\
- \text { Ability to carry out an information search }\end{array}$ & 1,5 & 1,5 & 1,5 & 1,5 & 3 & 1,87 & $\mathrm{~A}$ \\
\hline $\begin{array}{l}- \text { Ability to work with a book, directories } \\
\text { and other primary sources }\end{array}$ & 1,5 & 1,5 & 1,5 & 1,5 & 3 & 1,87 & $\mathrm{~A}$ \\
\hline $\begin{array}{l}- \text { Ability to work with technical sources } \\
\text { of information }\end{array}$ & 1,5 & 1,5 & 1,5 & 1,5 & 3 & 1,75 & $\mathrm{~L}$ \\
\hline $\begin{array}{l}\text { 3. Creative abilities } \\
- \text { ability to generate ideas, to put forward } \\
\text { the research hypothesis }\end{array}$ & 0,5 & 0,5 & 0,5 & 0,5 & 0,5 & 0,5 & $\mathrm{~L}$ \\
\hline- the ability to fantasize, to imagine & 1,5 & 1 & 0,5 & 1 & 2,5 & 1,37 & $\mathrm{~L}$ \\
\hline $\begin{array}{l}\text { - ability to transfer knowledge, skills in } \\
\text { new problem situations }\end{array}$ & 1 & 1 & 1 & 1 & 1,5 & 1,12 & $\mathrm{~L}$ \\
\hline - ability to distinguish contradictions & 1,5 & 1 & 0,5 & 1 & 3 & 1,5 & $\mathrm{~L}$ \\
\hline $\begin{array}{l}\text { - the ability to represent the inertia of } \\
\text { thinking }\end{array}$ & 0,5 & 1 & 0,5 & 0,7 & 1 & 0,8 & $\mathrm{~L}$ \\
\hline $\begin{array}{l}4 . \text { Prognostic skills: } \\
- \text { the ability to predict the consequences } \\
\text { of the pedagogical process }\end{array}$ & 2 & 1,5 & 1 & 1,5 & 3,5 & 2,0 & $\mathrm{~L}$ \\
\hline $\begin{array}{l}\text { - the ability to carry out a retrospective } \\
\text { analysis of the pedagogical process }\end{array}$ & 1,5 & 1 & 1 & 0,8 & 3,5 & 1,5 & $\mathrm{~A}$ \\
\hline- ability to extrapolate & 1,5 & 1 & 1 & 0,8 & 4 & 1,6 & $\mathrm{~L}$ \\
\hline
\end{tabular}

Date of completion

Experts: 1. Balashova S. P.

2. Golovko N. I.

3. Levytska L. A.

For the quantitative characterization of the level of the formation of research skills, we calculated the coefficients of the formation of analytical-synthetic, informational, creative and predictive skills, as well as the coefficient of formation of the students' research skills, through which one can analyze the degree of formation of research skills that contribute to the creative development of the future researcher, to study the dynamics of their development during study in a higher education institution by the method of S. Sysoeva [3].

We have entered the following notation:

the number of indicators that have a high level of manifestation;

the number of indicators that have an average level of manifestation;

the number of indicators that have a low level of manifestation.

$\mathrm{Q}$ - total number of indicators.

Then: $\mathrm{Q}=\mathrm{m}+\mathrm{p}+\mathrm{n}$

Based on the definition of high, medium and low levels of manifestation of indicators, one can deduce the coefficient of the level of formation of student's research skills:

$\mathrm{K}=(\mathrm{m}+1 / 2 \mathrm{p}) / \mathrm{Q}$

At the same time, in our opinion, high-level indicators are used with a weight of 1 , average -0.5 , low -0 .

For example, for the map given in Table 1, which was filled for one student, we have: 
$\mathrm{m}=0 ; \mathrm{p}=5 ; \mathrm{n}=10 \mathrm{~K}=(0+1 / 2.5) / \mathrm{Q} 15=0.17$

We will assume:

if $\mathrm{K}$ is between 0 and 0.33 , then the level of formation of students' research skills is considered low $(0<\mathrm{K}<0.33)$;

if $\mathrm{K}$ is between 0.33 and 0.66 , then the level of formation of students' research skills is considered low $(0.33<\mathrm{K}<0.66)$;

if $\mathrm{K}$ is between 0.66 and 1 , then the level of development of students' research skills is considered low $(0.66<\mathrm{K}<1.0)$.

Based on this, the level of formation of students' research skills is defined as:

low - research skills are limited in the educational process;

average - research skills are mainly manifested at an adequate level in different types of educational activities;

high - the creative use of research skills in the learning process and in different types of practices.

Similarly we can define the coefficient of formation level of analytical-synthetic, informative, creative and prognostic students' skills.

For example, the coefficient of formation level of analytical-synthetic skills of a student is determined (look at the Table 1)

$\mathrm{K}=(0+1 / 2 * 2) / 4=0.22$

Where $\mathrm{m}=0$ it is the number of analytical and synthetic skills that have a high level of manifestation;

$\mathrm{p}=$ number of analytical and synthetic skills that have an average level of manifestation;

$\mathrm{n}=$ number of analytical and synthetic skills that have a low level of manifestation;

$\mathrm{Q}=4$ - total number of students' analytical and synthetic skills introduced.

On the basis of studying the coefficients of the formation of analytical-synthetic, informational, creative and predictive skills, as well as determining the coefficient of students' research skills, a map is filled out to analyze students' research skills (look at the Table 2).

\section{The table of the study of the formation of research skills of Maryna Smirnova course 1 Taras Shevchenko Kyiv National University}

Table 2

\begin{tabular}{|c|c|c|c|c|c|}
\hline Kas & K inf & K kr & Kpr & K rs & $\begin{array}{c}\text { The level of the } \\
\text { formation of } \\
\text { research skills }\end{array}$ \\
\hline 0.25 & 0.33 & 0 & 0.16 & 0.17 & $\mathrm{~L}$ \\
\hline
\end{tabular}

Based on the results we have built a research profile of the student's creative personality. We created a student research profile with her future pedagogical creative activity. To do this, we studied the orientation of the individual for future pedagogical activities, the development of personal qualities and abilities, which are dominate research skills. 


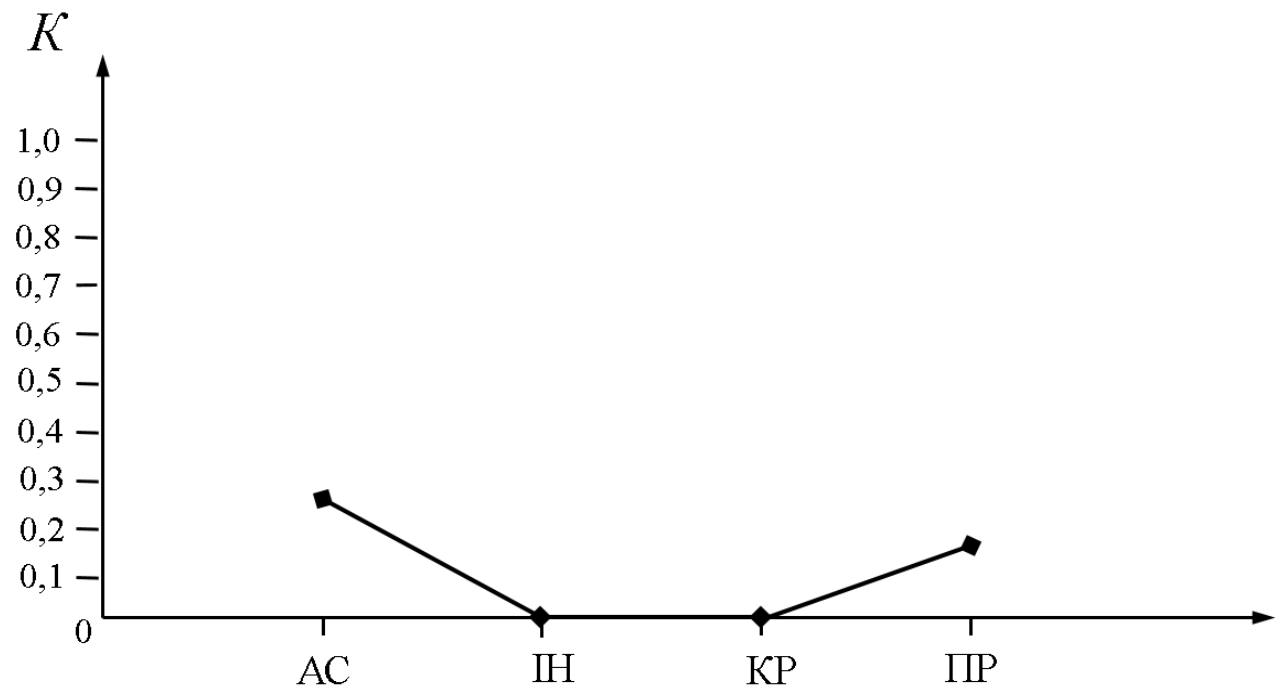

Graph. 1. Student profile of Maryna Smirnova

In our research we rely on the definition of the profile of a creative personality as a graphic representation of the main personal creative qualities, in particular, research skills that affect the success of creative activity, and create the prerequisites for pedagogical creativity. The purpose of this introduction is related to the need for pedagogical leadership in the formation of the students' creative personality, in particular, the research skills in the educational process and during the passage of various types of practice, the possibility of making adjustments to the creative pedagogical activity of future teachers in order to further develop them as specialist-researchers.

The students' research profile allows universities' teaching staff to direct their activities to the development of students' research skills, as well as to manage this process. In addition, it provides an opportunity to analyze individual groups of research skills for the purpose of their enhanced development in the educational process.

Analysis of the research abilities of each student of the group allows to analyze the "research portrait" of the student group and give grounded recommendations to teachers, methodologists to improve the efficiency of the educational process, to direct its development of student research activities.

Investigation of research skills of the academic group students should start at the beginning of the first year and conduct the following stages:

- investigation of individual students' research skills: definition of coefficients of development of analytical-synthetic, informational, creative and predictive skills, as well as coefficient of formation of research skills;

- construction of a research group of students in the training group;

- analysis of research skills of students in this group;

- the development of recommendations for teachers on the optimal organization of educational process, aimed at the formation and development of students' research skills. 
Proceeding from the above, during the pedagogical assessment of the level of the formation of research skills, it was found that the students of the first course have the most developed analytical-synthetic (52\%) and informational $(68 \%)$ abilities and the least developed creative (12\%) and prognostic (24\%).

The obtained data of self-assessment of students' research skills indicate its change from course to course. Sufficiently first-year students have high self-esteem. It is slightly lowered in $2^{\text {nd }}$ and $3^{\text {rd }}$ courses, and then again increases by $4^{\text {th }}$ (graduation) course. This is due to the fact that first-year students can not objectively assess their own level of development of research skills, especially the need for their application in the future profession. But with the inclusion of them in teaching and investigation and research work, the students' view of the formation of their research skills and the need for their formation are changing. This leads to a change in self-esteem. However, we want to note, firstly, that the self-esteem of almost all students is overstated. Secondly, there is a tendency for students with a high academic grade at a university to more objectively evaluate their abilities than students who have an average and a low grade of teaching. As a rule, they estimate the level of development of research skills higher than the objective level of their formation. In the third, the subjective self-esteem of a student does not coincide with the objective assessment of experts during the entire time of studying students at the university. This is due to the fact that during the entire period of study at the university, most teachers have paid little attention to the formation of students' interest in research activities. And as a result, the majority of students do not form a holistic attitude to research work, understanding its functions in professional development.

In order to effectively develop the research skills of future teachers and to check the effectiveness of pedagogical technology, intermediate sections were made to study the level of their formation (each year of study), and after the results were handled, seminars were conducted with teachers in order to make corrections in the educational process. As evidenced by the results obtained regarding the level of development of research skills among students from the first to fourth years (educational level "Bachelor"), the growth of their development increases in the input of inclusion of students in research work, the use of innovative forms and methods of teaching, as well as in practical pedagogical activity.

The method proposed by us can be the basis for the work in institutions of higher education to create favorable conditions for the formation and development of a future specialists' research skills in the educational process and during the course of practice. At the same time, it was emphasized that taking into account the results of pedagogical evaluation, information is only for university lecturers who should implement an individual and differential approach to learning in order to maximally contribute to the formation and development of research skills of students, knowledge of their level of formation in students and the entire academic group gives the teacher the opportunity to choose the most effective ways of developing research skills of students, and also makes it possible to make adjustments to the forms and methods of teaching that contribute development of the future teacher as a researcher.

Prospects for further research in-depth study of foreign experience with varieties of educational assessment to determine the skill level of the learner, including research skills. 


\section{СПИСОК ВИКОРИСТАНИХ ДЖЕРЕЛ}

1. Балашова С. П. Формування дослідницьких умінь у студентів педагогічного коледжу в процесі вивчення природознавчих дисциплін: автореф. дис. ... канд. пед наук: 13.00.04. Київ, 2000. 20 с.

2. Балашова С. П., Головко Н. І. Науково-дослідницька робота студентів як засіб творчої діяльності студентів. Вісник Київського національного університету імені Тараса Шевченка. Серія: Педагогіка. Київ: ВПЦ «Київський університет», 2016. Вип. 1(3). С. 6-9.

3. Сисоєва С. О. Підготовка вчителя до формування творчої особистості учня. Київ: Поліграфкнига, 1996. $406 \mathrm{c}$.

\section{REFERENCES}

1. Balashova, S. P. (2000). Formuvannia doslidnyts'kykh umin' u studentiv pedahohichnoho koledzhu v protsesi vyvchennia pryrodoznavchykh dystsyplin. Extended abstract of candidate's thesis. Kyiv [in Ukrainian].

2. Balashova, S. P., Holovko N. I. (2016). Naukovo-doslidnyts'ka robota studentiv iak zasib tvorchoii diial'nosti studentiv. Visnyk Kyivskoho natsional'noho universytetu imeni Tarasa Shevchenka. Pedahohika. Kyiv: VPTS “Kyivs'kyi universytet”, 1(3), 6-9 [in Ukrainian].

3. Sysoieva, S. O. (1996). Pidhotovka vchytelia do formuvannia tvorchoi osobystosti uchnia. Kyiv: Polihrafknyha [in Ukrainian]. 